\title{
KONSEP PERPUSTAKAAN, SIKAP PUSTAKAWAN, DAN BOOK VANDALISM DALAM FILM 'MR. BEAN' EPISODE 'THE LIBRARY'
}

\author{
Oleh: Fiqru Mafar*
}

\begin{abstract}
Abstrak
Film merupakan interpretasi dari kondisi sosial suatu masyarakat. Oleh karena itu, di dalam sebuah film, terdapat pesan-pesan tersirat yang ingin disampaikan oleh sutradara. Tidak banyak film yang menghadirkan perpustakaan sebagai salah satu setting dalam adegannya, salah satunya adalah film 'Mr. Bean' episode 'The Library'. Tulisan ini bertujuan untuk mengungkap konsep perpustakaan, sikap pustakawan dan book vandalism yang ditampilkan dalam film tersebut. Metode yang digunakan adalah metode kualitatif dengan menampilkan data secara deskriptif. Dari hasil penelitian diperoleh hasil bahwa konsep perpustakaan dalam film tersebut masih terbatas pada adanya gedung. Pelayanan yang diterapkan adalah pelayanan dengan sistem tertutup. Pustakawan memiliki sikap yang ramah dan sopan dalam melayani pemustaka. Book vandalism yang dilakukan oleh Mr. Bean merupakan suatu bentuk kriminalitas yang tidak dapat ditiru.
\end{abstract}

Kata Kunci: Perpustakaan, Sikap Pustakawan, Book Vandalism, Mr. Bean.

\section{Pendahuluan}

Ide pembuatan suatu film tidak terlepas dari fenomena yang terjadi di masyarakat. Fenomena tersebut dikemas sedemikan rupa oleh sutradara sehingga menjadi suatu tontonan yang menarik untuk dinikmati. Kreativitas dan ide-ide unik sutradaralah yang memainkan peran penting sehingga sebuah film tersebut dapat dinikmati oleh penonton.

Siapa yang tidak kenal Mr. Bean? Film pendek berseri ini telah melekat dan banyak diminati oleh para penggemar film komedi Indonesia. Dalam film tersebut, Rowan Atkinson berperilaku dan bertingkah polah aneh. Tidak jarang, kejadian yang ditampilkan adalah kejadian biasa yang dapat ditemukan di keseharian masyarakat. Namun, dengan sedikit sentuhan kreativitas, kekonyolan-kekonyolan Mr. Bean mampu membuat penonton tertawa terpingkalpingkal.

Dalam suatu episode, Mr. Bean berada dalam sebuah perpustakaan. Seperti biasa, dalam setiap episode, pasti ada saja kekonyolan dan tingkah laku aneh yang ditampilkan, begitu juga dalam film tersebut. Mr. Bean, dengan wajah polos dan tanpa merasa bersalah, mampu menghadirkan sesuatu yang lucu, meskipun hanya berada dalam satu setting tempat, perpustakaan.

Dalam tulisan ini, penulis tidak akan membahas bagaimana kekonyolan $\mathrm{Mr}$. Bean bisa terjadi. Tulisan ini akan membahas tentang konsep perpustakaan dan sikap pustakawan yang ditampilkan dalam film tersebut.

\section{Landasan Teori}

\section{Perpustakaan}

Perpustakaan merupakan suatu tempat, bangunan, ruang atau beberapa ruangan, yang khusus digunakan untuk memanfaatkan dan memelihara koleksi buku dan lain-lain (Prytherch, 2005:416). Pengertian ini sejalan dengan yang dikemukakan oleh Sulistyo-Basuki (1991) yang menyatakan bahwa perpustakaan merupakan sebuah ruangan atau gedung yang digunakan untuk menyimpan buku dan terbitan lainnya yang biasanya disimpan menurut tata susunan tertentu yang digunakan pembaca bukan untuk dijual. Dalam definisi ini, ada beberapa syarat yang harus terpenuhi dalam sebuah perpustakaan, yaitu gedung, koleksi, dan dimanfaatkan tidak untuk dijual.

Koleksi yang ada di perpustakaan dikelola sedemikian rupa sehingga dapat dimanfaatkan oleh pemustaka. Pengelolaan koleksi dilakukan melalui beberapa tahapan yaitu perencanaan, pengembangan, pemilihan, pengadaan, pengolahan, pemanfaatan, pemeliharaan, evaluasi, preservasi, dan penyiangan. Dalam tulisan ini, penulis tidak akan menjelaskan masing-masing tahapan yang ada. Penulis hanya ingin menjelaskan secara singkat mengenai tahap pemanfaatan atau pelayanan.

Terdapat dua macam sistem pelayanan di dalam perpustakaan, yaitu tertutup dan terbuka. Sistem pelayanan tertutup adalah suatu sistem pelayanan dimana staf mengambilkan item untuk pengguna (Stevenson dan Collin, 2006:36). Dalam sistem ini, pustakawan harus aktif dalam proses pelayanan. Pemustaka tidak diperkenankan menuju ke rak koleksi 
untuk memilih sendiri koleksi yang diinginkan. Pemustaka harus terlebih dahulu memesan koleksi kepada pustakawan dan pustakawanlah yang mengambilkan koleksi di rak untuk kemudian diberikan kepada pemustaka.

Sistem pelayanan yang kedua adalah sistem pelayanan terbuka, yaitu suatu sistem pelayanan dimana pemustaka dapat mencari dan menemukan sendiri apa yang mereka inginkan (Stevenson dan Collin, 2006:145). Dalam sistem ini, pemustaka diberikan kebebasan untuk menuju dan memilih buku di antara jajaran rak di perpustakaan. Dengan demikian, sistem ini memungkinkan pemustaka untuk menemukan koleksi lain yang berhubungan dengan informasi yang mereka cari.

Penerapan sistem layanan saja tidak cukup. Perpustakaan juga harus mampu memberikan kenyamanan kepada pemustaka. Keberadaan lingkungan ruang yang nyaman, rapi dan bersih dapat menjadikan suasana yang kondusif untuk melakukan penelusuran sehingga akan memberikan kepuasan jasmani bagi pengguna (Mafar, 2006:66). Di samping itu, keberadaan peralatan pendukung seperti adanya meja baca yang sesuai akan mampu meningkatkan kenyamanan sehingga pemustaka betah berlama-lama diperpustakaan.

\section{Sikap Pustakawan dalam Melayani Pemustaka}

Pustakawan dapat diartikan sebagai seseorang yang terlatih di bidang kepustakawanan dan bekerja di perpustakaan (Stevenson dan Collin, 2006:118). Lasa Hs. (2009:295) menyatakan bahwa pustakawan adalah seseorang yang melaksanakan kegiatan perpustakaan dengan jalan memberikan pelayanan kepada masyarakat sesuai dengan tugas lembaga induknya berdasarkan ilmu perpustakaan, dokumentasi, dan informasi yang dimilikinya melalui pandidikan. Dari dua pengertian ini terlihat jelas bahwa syarat untuk dapat disebut sebagai pustakawan harus memiliki keahlian di bidang kepustakawanan dan bekerja di perpustakaan.

Dalam memberikan pelayanan kepada pemustaka, pustakawan dituntut untuk mampu memberikan berbekal keahlian yang dimiliki. Keahlian tersebut tidak hanya tentang keahlian teknis dalam pengelolaan perpustakaan, tetapi juga keterampilan sosial lainnya. Pustakawan harus membekali dirinya dengan soft skill yang dapat membantu mereka mempertemukan antara pemustaka dengan informasi yang mereka butuhkan.

Dalam suatu pelayanan memang dibutuhkan hubungan interpesonal yang baik antara petugas dengan pemustaka untuk mencapai tujuan suatu pelayanan yaitu terpenuhinya kebutuhan informasi (Mafar, 2006:64). Adanya komunikasi yang baik dengan pemustaka, sikap yang ramah, dan penampilan pustakawan yang menarik, diharapkan akan mampu memberikan suasana kekeluargaan di dalam perpustakaan. Dengan demikian, kenyamanan dan kepuasan pengguna dalam memanfaatkan perpustakaan dapat tercapai.

\section{Book Vandalism}

Dalam UU No. 43 Tahun 2007 tentang Perpustakaan Pasal 1 disebutkan bahwa pemustaka adalah perseorangan, kelompok orang, masyarakat, atau lembaga yang memanfaatkan fasilitas layanan perpustakaan. Dalam undang-undang tersebut juga disebutkan bahwa pengelolaan perpustakaan bertujuan untuk memenuhi kebutuhan pemustaka. Hal ini berarti bahwa kepuasan pemustaka adalah tujuan utama dari perpustakaan.

Agar dapat memanfaatkan perpustakaan secara maksimal, maka pemustaka terlebih dahulu harus mengikuti user education. User education adalah pelatihan tentang bagaimana menggunakan perpustakaan (Feather dan Sturges, 2003:646). Meskipun demikian, tidak semua pemustaka mampu menerapkan apa yang mereka peroleh melalui pelatihan yang telah diadakan. Kondisi tersebut menyebabkan adanya perilaku yang berbeda-beda di antara pemustaka. Tidak jarang ditemui pemustaka yang merusak buku yang mereka pinjam. Hal ini dikenal di perpustakaan dengan nama kekerasan kepada buku(book vandalims).

Banyak sekali bentuk kekerasan kepada buku di perpustakaan, bahkan di perpustakaan besar sekalipun'. Untuk mengatasi hal ini, perpustakaan dapat mengambil langkah-langkah sebagai berikut (Stecewycz, 1983:1).

1. Pustakawan memasang pengumuman bahwa perusakan buku adalah suatu tindak kriminal dan

\footnotetext{
${ }^{1}$ Pada tahun 1997, di Ohio University terdapat 200 lebih buku yang 'kehilangan' gambar di dalamnya. Contoh lain, di Alabama, kekerasan terhadap buku pernah dilakukan oleh seseorang yang mengidap phidopilia. Pelaku sengaja merobek foto anak-anak yang ada di buku dan menempelkannya pada gambar wanita dewasa telanjang. Hal itu memberikan kepuasan tersendiri bagi si pelaku.
} 
akan mendapatkan hukuman.

2. Perpustakaan menghimbau kepada seluruh pemustaka untuk melaporkan yang ia temui pada koleksi perpustakaan.

3. Pustakawan, secara periodik, melakukan pengecekan dan perbaikan pada buku-buku yang mengalami kerusakan.

Beberapa langkah yang ditawarkan di atas memang tidak mudah untuk dilakukan. Berbagai kendala akan dihadapi untuk mewujudkannya. Namun, dengan keseriusan dan kontinuitas yang tinggi, penulis yakin perpustakaan akan mampu mengurangi perusakan buku yang terjadi di instansinya masing-masing.

\section{Metode Penelitian}

Objek penelitian ini adalah film yang berjudul 'Mr. Bean' episode 'The Library'. Untuk mendapatkan hasil analisis yang baik, penulis mengumpulkan data mengenai film ini dari berbagai sumber. Penulis menggunakan film sebagai data utama dalam penelitian. Selain itu, penulis juga menggunakan data yang diperoleh dari berbagai tulisan yang berisi teoriteori yang berkaitan dengan konsep-konsep dalam penelitian ini.

Setelah data-data terkumpul, penulis mengelompokkannya berdasarkan topik dan jenis data yang ada. Analisa data dilakukan dengan metode qualitatif. Bogdan dan Taylor dalam Moleong (1993:3) mengungkapkan bahwa penelitian kualitatif adalah suatu penelitian yang menghasilkan data deskriptif berupa kata-kata tertulis atau lisan dari orang dan prilaku yang dapat diamati. Dalam hal ini, yang diamati adalah adegan-adegan dan setting lokasi yang ditampilkan dalam film. Dari pengertian tersebut, maka penelitian ini menggunakan metode deskriptif untuk menampilkan hasil analisa yang penulis lakukan. Dengan demikian, laporan penelitian akan berisi kutipan-kutipan data untuk memberi gambaran penyajian laporan tersebut (Moleong, 1993:6).

\section{Sinopsis $^{2}$}

Film yang berdurasi selama 9 menit 17 detik ini lebih mirip dengan film bisu karena tidak terdengar suara dialog antar masing-masing pemain. Diawali dengan menampilkan sebuah ruangan perpustakaan

\footnotetext{
${ }^{2}$ Dikutip dari film 'Mr. Bean' episode 'The Library'
}

yang cukup tenang. Di dalamnya terdapat buku-buku tertata rapi di rak, beberapa pemustaka yang sedang asyik membaca di meja baca yang disediakan, dan seorang laki-laki paruh baya yang berperan sebagai pustakawan dengan pakaian rapi berjas dan berdasi.

Adegan dilanjutkan dengan kedatangan Mr. Bean, memakai setelan jas berwarna cokelat dan menjinjing tas dengan warna yang sama, yang disambut ramah oleh pustakawan. Terlihat Mr. Bean berdialog dengan pustakawan mengenai informasi yang terdapat di suatu buku yang dia inginkan. Kemudian pustakawan mempersilahkan Mr. Bean duduk di salah satu meja baca yang tersedia, sementara dia mengambil buku yang dimaksud. Sambil mempersilahkan, tidak lupa pustakawan tersebut memberikan isyarat kepada Mr. Bean untuk tidak bersuara sedikitpun. Dengan langkah yang sangat hati-hati agar tidak menimbulkan suara sedikitpun, Mr. Bean menuju meja baca yang dimaksud.

Di meja baca, terdapat seorang pria dengan buku besar di atas sebuah tatakan buku sedang asyik membaca. Ketika Mr. Bean datang dan menggeser kursi, terdengar suara decitan. Sang Pria merasa terganggu dan menoleh ke arah Mr. Bean. Mr. Bean pun meminta maaf kepada pria tersebut.

Mr. Bean mengeluarkan peralatan menulis, selembar kertas, buku tulis, dan tempat pensil dengan resleting di atasnya, dari dalam tasnya. Dengan sangat hati-hati, dia membuka tempat pensil. Namun celaka, resleting tempat pensil tersebut kurang licin sehingga menimbulkan suara berderit. Dengan agak ketakutan, dia mengeluarkan botol berisi cairan pelicin dan menuangkannya ke resleting tersebut, dengan maksud agar lebih licin sehingga tidak menimbulkan suara lagi ketika dibuka, dan usahanya berhasil.

Kekonyolan Mr. Bean tidak hanya berhenti di situ. Sambil menunggu buku pesanannya datang, tiba-tiba dia cegukan berkali-kali. Suara cegukannya makin lama makin keras dan kembali mengganggu konsentrasi pria yang sedang asyik membaca tadi. Di tengah kepanikan, Mr. Bean berusaha untuk menahan cegukan yang ia rasakan. Setelah mencoba beberapa cara, akhimya dia berhasil menghilangkan cegukan tersebut.

Sambil menunggu, Mr. Bean mengeluarkan sarung tangan khusus dari dalam tasnya dan memakainya. Setelah beberapa lama menunggu, buku yang dia pesan pun datang. Layaknya di sebuah restoran mewah, pustakawan mengantarkan buku yang diinginkan oleh Mr. Bean. Tidak hanya itu, dia bahkan 'menghidangkan' buku tersebut dengan 
membuka halaman yang berisi informasi yang dipesan.

Dengan sangat hati-hati Mr. Bean membuka halaman demi halaman. Namun, kesialan tetap saja berpihak padanya. Tiba-tiba dia bersin dan menimbulkan suara yang terdengar oleh pria di sampingnya. Sang Pria pun untuk yang kesekian kalinya merasa terganggu. Karena merasa takut dan gugup, tanpa sengaja Mr. Bean mencorat-coret salah satu halaman buku yang dia pegang. Dia pun mencoba berbagai cara untuk menghapus coretan tersebut. Namun, bukannya berhasil, buku tersebut malah rusak dibuatnya.

Di tengah usahanya memperbaiki kerusakan, datang pustakawan berkeliling mengontrol keadaan. Dia pun berhenti sejenak. Setelah pustakawan tersebut pergi, Mr. Bean melanjutkan kegiatannya.

Melihat gerak-gerik Mr. Bean, pustakawan menjadi curiga. Dia pun berpura-pura berkeliling sambil mengeluarkan suara batuk. Mr. Bean mengetahui hal itu dan justru memanfaatkan suara batuk pustakawan untuk merobek halaman buku yang rusak. Namun, bukannya menyelesaikan masalah, malah timbul masalah lain karena lebih banyak halaman buku yang rusak.

Waktu berkunjung pun telah habis. Dengan sikap elegan dan ramah, pustakawan menghampiri Mr. Bean dan pembaca lain untuk memberitahukan hal tersebut. Mengetahui hal itu, pria itu berkemas. Hal ini dimanfaatkan oleh Mr. Bean untuk menukar buku yang rusak dengan buku yang telah dibaca oleh pria tadi tanpa sepengetahuannya.

Dengan santai Mr. Bean membawa buku dan tasnya dan menuju pintu keluar. Di dekat pintu, pustakawan sudah menunggu untuk menerima dan memeriksa buku yang telah dibaca oleh pemustakanya. Karena akal liciknya, Mr. Bean lolos untuk sementara, dan laki-laki lain yang dituduh telah merusak buku oleh pustakawan. Namun, yang baik haruslah menang, Mr. Bean kembali untuk mengambil sesuatu yang tertinggal di buku yang rusak, dan di situlah ketahuan kalau dia yang merusak buku tersebut.

\section{Hasil Analisa}

\section{Konsep Perpustakaan}

Konsep perpustakaan yang ditampilkan dalam film ini tidak berbeda dengan definisi perpustakaan yang ada sebagai sebuah gedung. Hal ini terlihat pada setting tempat kejadian berlangsung. Keseluruhan adegan dilakukan di dalam perpustakaan. Adanya rak koleksi, meja baca, dan koleksi yang tertata rapi merupakan bukti bahwa konsep perpustakaan dalam film ini masih menganggap bahwa perpustakaan merupakan gedung tempat mengelola koleksi buku.

Sistem pelayanan yang diterapkan adalah sistem pelayanan tertutup. Dalam film ini, Mr. Bean tidak dapat mengakses koleksi secara langsung. Dia harus berdialog dengan pustakawan untuk mendapatkan koleksi yang diinginkan. Pustakawanlah yang mengakses koleksi di rak dan mengantarkan koleksi tersebut kepada pemustaka. Penerapan sistem ini memiliki banyak keuntungan. Salah satu diantaranya adalah koleksi yang selalu tertata rapi karena pustakawan yang mengambil dan mengembalikan koleksi dirak.

Film ini juga menampilkan adanya peralatan tambahan yang dapat menambah kenyamanan pemustaka. Adanya tatakan buku, membuat Sang Pria di samping Mr. Bean merasa nyaman dan dapat berkonsentrasi dalam membaca buku di perpustakaan tersebut. Fitur tambahan ini merupakan suatu bentuk usaha untuk memberikan kenyamanan dan kepuasan pemustaka dalam memanfaatkan perpustakaan.

Selain itu, ketenangan dalam perpustakaan juga terjaga dengan baik. Pemustaka yang berkunjung di perpustakaan tidak diperkenankan untuk menimbulkan kegaduhan yang dapat mengganggu konsentrasi pemustaka. Hal ini terlihat dengan adanya himbauan dari pustakawan untuk menjaga ketenangan di perpustakaan. Namun, kondisi ini justru menimbulkan masalah lain. Pemustaka harus sangat berhati-hati dalam melakukan aktivitasnya sehingga dapat mengganggu kenyamanan pribadi seseorang.

\section{Sikap Pustakawan dalam Pelayanan}

Pustakawan dalam film ini menggunakan setelan jas yang rapi. Hal ini menunjukkan bahwa pustakawan yang ditampilkan telah menganggap profesinya sebagai salah satu profesi yang terhormat. Kondisi ini menunjukkan bahwa pustakawan telah mengakui bahwa profesi pustakawan merupakan profesi yang harus dilakukan secara profesional. Oleh karena itu, dia berusaha untuk menjaga penampilan agar citra pustakawan sebagai tenaga profesional tetap melekat pada dirinya. Adanya penampilan yang rapi akan mampu memberikan kepercayaan kepada pemustaka mengenai keahlian yang dimiliki oleh pustakawan.

Sikap ramah juga mampu ditampilkan oleh pustakawan dalam film ini. Hal tersebut terlihat pada 
saat pustakawan menyambut kedatangan Mr. Bean. Dengan sopan pustakawan melakukan dialog mengenai buku apa yang ia cari. Selain itu, sikap ramah dan sopan juga ditunjukkan ketika pustakawan memberitahukan bahwa waktu berkunjung telah habis. Dengan sopan pustakawan menghampiri pemustaka satu-persatu dan memmberitahukan bahwa jam kunjung perpustakaan telah habis.

Sikap ramah dan sopan yang ditampilkan oleh pustakawan merupakan salah satu bentuk dari penerapan keterampilan sosial di perpustakaan. Pustakawan tidak hanya memberikan pelayanan kepada pemustaka melalui pinjam-meminjam koleksi perpustakaan, tetapi juga mampu menampilkan sifat yang mampu memberikan suasana kekeluargaan di dalam perpustakaan.

Sikap lain yang patut ditiru adalah adanya pelayanan berkualitas yang diberikan kepada pemustaka. Dalam mengantarkan 'pesanan' buku, pustakawan membawa buku tersebut dengan sikap layaknya pelayan restoran menghantarkan hidangan. Buku tersebut dibawa dalam keadaan terbuka pada halaman yang berisi informasi yang diinginkan oleh pemustaka. Kemudian dengan perlahan buku terebut 'dihidangkan' dan pemustaka ditunjukkan bahwa pada halaman tersebut terdapat informasi yang dia inginkan. Pelayanan tambahan ini menjadikan pemustaka merasa benar-benar dihargai. Dengan demikian, kepuasan pemustaka akan dapat terjaga.

\section{Book Vandalism di Perpustakaan.}

Book vandalism yang ditampilkan dalam film ini berawal dari ketidaksengajaan. Namun, alih-alih ingin memperbaiki kerusakan, Mr. Bean justru membuat kerusakan yang lebih banyak. Sikap Mr. Bean ini merupakan sikap yang sangat disayangkan.

Seharusnya, ketika pemustaka menemui kerusakan pada buku, dia memiliki kewajiban untuk melaporkannya kepada pustakawan yang bertugas. Pemustaka seharusnya menyerahkan perbaikan buku yang rusak kepada pustakawan. Hal ini merupakan tugas rutin pustakawan sebagai bentuk dari preservasireservasi.

Dalam kasus ini, pustakawan haruslah memiliki keahlian dalam hal perbaikan buku. Keahlian seperti penjilidan, merekatkan kembali halaman yang sobek, dan lain sebagainya merupakan kemampuan yang wajib dimiliki oleh pustakawan. Pustakawan sebagai book doctor harus mampu merawat dan memperbaiki koleksi yang ada di perpustakaan.
Pengecekan yang dilakukan oleh pustakawan dalam film ini merupakan salah satu contoh kegiatan yang dapat menghindari terjadinya book vandalism. Pada bagian akhir film, ditampilkan pustakawan melakukan pengecekan halaman demi halaman koleksi yang dikembalikan oleh pemustaka. Hal ini baik sekali dilakukan secara terus menerus dalam rangka untuk menemukan sedini mungkin kerusakan yang ada. Selain itu, dengan adanya pengecekan semacam ini, pelaku vandalism dapat 'ditangkap' dan diberi hukuman yang dapat membuat mereka jera.

\section{Simpulan}

Konsep perpustakaan yang ditampilkan dalam film ini sama dengan definisi perpustakaan sebagai sebuah gedung. Sistem pelayanan yang diterapkan adalah sistem pelayanan tertutup. Pustakawan dalam film ini digambarkan sebagai petugas yang berpenampilan menarik dan ramah terhadap pemustaka yang dilayaninya.

Book vandalism sebagaimana yang ditampilkan dalam film ini merupakan sesuatu yang tidak patut untuk ditiru. Untuk mengatasinya, pustakawan harus memberikan pemahaman tentang bagaimana memanfaatkan buku yang benar tanpa menimbulkan kerusakan. Di samping itu, pustakawan juga harus membuat peraturan mengenai apa yang harus dilakukan oleh pemustaka jika menemukan atau terjadi kerusakan pada buku. Hal ini dilakukan untuk menghindari kerusakan yang lebih parah lagi pada buku tersebut.

\section{DAFTAR PUSTAKA}

1997. "Ohio college libraries hit by book vandalism." The Chronicle of Higher Education, October 24, 1997, A6. http://www.proquest.com/ (diakses pada 08 November 2010).

-2005. "Police Investigate Book Vandalism in Alabama." American Libraries, April 1, 2005, 17 18. http://www.proquest.com/ (diakses pada 8 November 2010).

Atkinson, Rowan. 2010. "Mr. Bean Episode The Library". Inggris: Tiger Television. Diambil dari http://www. 4shared.com/video/ofHmB7Q2/Mr Bean_The_Library.htm/ pada 06 November 2010.

Feather, John dan Paul Sturges [Ed.]. 2003. International Encyclopedia of Information and Library Science. London: Routledge. 
Lasa Hs. 2009. Kamus Kepustakawanan Indonesia. Yogyakarta: Pustaka Book Publisher.

Mafar, Fiqru. 2006. "Persepsi Pengguna Terhadap Kualitas Pelayanan Internet di Perpustakaan UPT Perpustakaan UIN Sunan Kalijaga Yogyakarta tahun 2006". Skripsi (Tidak diterbitkan). Yogyakarta: Jurusan Ilmu Perpustakaan Fakultas Adab UIN Sunan Kalijaga

Moleong, Lexy J. 1993. Metode Penelitian Kualitatif. Bandung: Remaja Rosda Karya.

Prytherch, Ray. 2005. Harrod's Librarians' Glossary and Reference Book: A directory of over 10,200 terms, organizations, projects and acronyms in the areas of information management, library science, publishing and archive management. England:Ashgate.

Simon, Rita James. "VANDALISM IN A UNIVERSITY LIBRARY - - WHO'S RESPONSIBLE?." Education 90, no. 1 (September 1969): 39. Academic Source Premier, EBSCOhost (diakses pada 08 November 2010).
Stecewycz, Anna. 1983. "Maag Officials Tear into Book Vandalism". Dalam The Jambar Vol. 64 No. 41.

Stevenson, Janet dan P. H. Collins. 2006. Dictionary of Information and Library Management. London: A \& CBlack.

Sulistyo-Basuki. 1991. Pengantar Ilmu Perpustakaan. Jakarta: Gramedia Pustaka Utama.

* Mahasiswa S2 Program Studi Interdiciplinery Islamic Studies Konsentrasi Ilmu Perpustakaan dan Informasi UIN Sunan Kalijaga Yogyakarta

* Pengajar Ilmu Perpustakaan Fakultas Ilmu Budaya, Universitas Lancang Kuning Pekan Baru Riau 